\title{
FATE AND OCCURRENCE OF ALKYLPHENOLIC COMPOUNDS IN SEWAGE SLUDGES DETERMINED BY LIQUID CHROMATOGRAPHY TANDEM MASS SPECTROMETRY
}

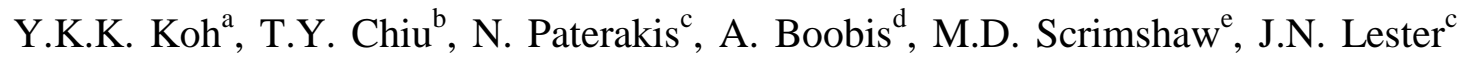 \\ and E. Cartmell ${ }^{\mathrm{c}^{*}}$
}

${ }^{a}$ Public Utilities Board, Technology and Water Quality Office, 40 Scotts Road \#15-01, Environment Building, 228231, Singapore.

${ }^{b}$ Earth Tech Engineering Limited, Wentworth Business Park, Tankersley, Barnsley, S75 3DL

${ }^{c}$ Centre for Water Science, School of Applied Science, Cranfield University, Bedfordshire, MK43 OAL, UK.

${ }^{d}$ Faculty of Medicine, Division of Experimental Medicine and Toxicology, Imperial College London, Hammersmith Campus, London, W12 ONN, UK.

${ }^{e}$ Institute for the Environment, Brunel University, Uxbridge, Middlesex, UB8 3PH, UK.

\begin{abstract}
An analytical method has been developed and applied to determine the concentrations of the non-ionic alkylphenol polyethoxylate surfactants and their metabolites alkylphenoxy carboxylates and alkyphenols in sewage sludges. The compounds were extracted with methanol/acetone $(1: 1 \mathrm{v} / \mathrm{v})$ from sludge, and concentrated extracts were cleaned up by silica solid phase extraction prior to determination by liquid chromatography tandem mass spectrometry. The recoveries, determined by spiking sewage sludge at two concentrations, ranged from $51 \%$ to $89 \%$ with method detection limits from $6 \mu \mathrm{g} \mathrm{kg}^{-1}$ to $60 \mu \mathrm{g} \mathrm{kg}^{-1}$. The methodology was subsequently applied to sludge samples obtained from a carbonaceous activated sludge plant, a nitrifying/denitrifying activated sludge plant and a nitrifying/denitrifying activated sludge plant with phosphorus removal. Nonylphenolic compounds were 2-3 fold higher in concentration compared to their octyl analogues. Long chain nonylphenol polyethoxylates $\left(\mathrm{NP}_{3-12} \mathrm{EO}\right)$ ranged from $163 \mu \mathrm{g} \mathrm{kg}^{-1}$ to $11754 \mu \mathrm{g} \mathrm{kg}^{-1}$. The estrogenic metabolite nonylphenol was present at concentrations ranging from $336 \mu \mathrm{g} \mathrm{kg}^{-1}$ to $6696 \mu \mathrm{g} \mathrm{kg}^{-1}$.

* corresponding author: e.cartmell@cranfield.ac.uk
\end{abstract}

Keywords: Alkylphenol; alkylphenol polyethoxylates; alkylphenoxy carboxylates; endocrine disrupter; sewage sludge. 


\section{INTRODUCTION}

Amongst the numerous organic micropollutants entering sewage treatment works [1] those with endocrine disrupting ability are major sources of concern [2-5]. Whilst estrogens constitute the major cause of endocrine disruption in wastewater [6] alkylphenoxy polyethoxylates (APEOs) also make a significant contribution $[3,7]$. During secondary aerobic biological wastewater treatment they are biodegraded by both percolating biological filters [8] and the activated sludge process $[9,10]$ resulting in reduced concentrations in the final effluent discharged. Biodegradation is incomplete resulting in the formation of a range of breakdown products including alkylphenols, nonylphenols and octylphenols. The breakdown of APEOs during secondary biological wastewater treatment has been the subject of extensive investigation [10-14], however, the precise mechanism(s) of breakdown and the factors controlling this are not fully understood [7]. Considerable importance is attached to the formation and subsequent breakdown of carboxylated species in determining residual effluent concentrations. It has been established that in laboratory generated activated sludge APEO degradation is an intracellular biological process [14]. However, as presently operated, the ability of biological wastewater treatment to fully remove APEOs and their breakdown products is limited [15]. When discharged to the aquatic environment via sewage effluent the compounds may undergo further degradation leading to the formation of more persistent compounds such as nonylphenol [5]. During wastewater treatment some of the APEOs and their metabolites are absorbed to solid phases, crude sewage solids in the case of primary sludge and bacterial cells in the case of secondary sludge. High sorption coefficients ( $\left.\log K_{o w} 4.12-4.48\right)$ for lipophlic nonyl- and octyl-phenolic compounds (NP, $\mathrm{NP}_{1-}$ ${ }_{2} \mathrm{EO}, \mathrm{OP}$ and $\left.\mathrm{OP}_{1-2} \mathrm{EO}\right)$ in particular, result in adsorption of these compounds onto primary and secondary sludge solids (return activated sludge - RAS/ surplus activated sludge - SAS). Therefore these compounds, which will then be removed with the sewage sludges and subjected to further treatment prior to re-use, should be analysed in sludge samples.

The determination of these compounds in wastewater matrices is well established [8, 16-20]. However, it is necessary to analyse these compounds in sewage sludge, including their breakdown products and particularly the carboxylated species, if a full assessment of their environmental significance is to be made. Whilst 
substantial data and methods exist for the determination of estrogens in sewage sludges and river sediments [7, 21], there are significantly less equivalent comprehensive methods for APEOs and their breakdown products in these matrices. This is due to the complexity of the sludge matrix and the major problems this poses to the extraction and clean-up of samples and the analysis of all organic micropollutants $[22,23]$.

Different analytical protocols have been proposed for the extraction of APEOs and their degradation products from solid samples (sewage sludge, sediment, soil) and have been extensively reviewed [17]. Numerous co-extractives interfere in the analysis of the target analytes, and the requirement for trace quantification, necessitates extensive extraction, clean-up and the application of sophisticated instrumentation to quantify these compounds. Only a few methods permit the simultaneous extraction and determination of the parent compounds and degradation products from solid environmental samples. These include sonication [24] or pressurized liquid extraction (PLE) $[25,26]$. The main drawback of PLE is the high initial investment in PLE equipment [27] whilst a previous study found lower APEO recoveries when employing the sonication extraction procedure compared to that using shaking extraction method [18].

A quantitative LC/MS/MS method to analyse these compounds in wastewaters has previously been reported [8] and this study aims to develop, evaluate and apply the approach to generate a robust methodology for the determination of these alkylphenolic compounds to include the polar carboxylic degradation products in a range of sewage sludge samples with the intention of minimising solvent use through the reduction of sample size. The impact of sample size and concentration factors on matrix effects has previously been observed to be of significance in relation to reducing matrix effects in the analysis of alklyphenols [8].

\section{EXPERIMENTAL}

\subsection{Sewage samples}

Sewage sludge samples were obtained from three sewage treatment works (STWs) for this study. All three were activated sludge plants (ASP), one carbonaceous (CAS), one a nitrifying/denitrifying plant (N/DN) and the third a 
nitrifying/denitrifying plant with phosphorus removal (N/DN-P) plant. At the CAS plant both primary sludge and the primary and surplus activated sludge (SAS) mixed sludge prior to anaerobic digestion was sampled on two separate occasions 12 months apart (Sample A April 2007 and B April 2008). For the N/DN plant primary sludge and return activated sludge (RAS) was sampled. At the N/DN-P plant, in addition to primary and RAS samples, liquors from the primary sludge drum thickeners were sampled (Table 1).

\section{Please insert Table 1 here}

\subsection{Reagents and chemicals}

The technical 4-nonylphenol mixture of various chain isomers and 4-tertoctylphenol were obtained from Sigma-Aldrich (Gillingham, Dorset, UK). The longchain APEO, NPEO (Igepal CO210, CO520, CO720) and OPEO (Igepal CA210, CA520, CA720) were available in a commercial surfactant mixture containing different oligomers also purchased from Sigma-Aldrich. The commercial NPEO and OPEO formulations contained oligomers with an average of 5 ethoxylate groups containing oligomers from 2 to 12 units. Nonyl- and octyl-phenoxy acetic acid $\left(\mathrm{NP}_{1} \mathrm{EC}, \mathrm{OP}_{1} \mathrm{EC}\right)$, 4-nonyl- and octylphenolmono- and diethoxylate $\left(\mathrm{NP}_{1-2} \mathrm{EO}, \mathrm{OP}_{1-}\right.$ $\left.{ }_{2} \mathrm{EO}\right)$ were obtained from QMX Laboratories (Thaxted, Essex, UK). Standards for $\mathrm{NP}_{2} \mathrm{EC}, \mathrm{NP}_{3} \mathrm{EC}, \mathrm{OP}_{2} \mathrm{EC}, \mathrm{OP}_{3} \mathrm{EC}$ were not commercially available. $\mathrm{NP}_{2} \mathrm{EC}$ and $\mathrm{NP}_{3} \mathrm{EC}$ were quantified with the $\mathrm{NP}_{1} \mathrm{EC}$ standard, assuming equal response factors. Similarly $\mathrm{OP}_{2} \mathrm{EC}$ and $\mathrm{OP}_{3} \mathrm{EC}$ were quantified with $\mathrm{OP}_{1} \mathrm{EC}$.

Acetone, ethylacetate, acetonitrile, methanol $(\mathrm{MeOH})$ and dichloromethane were obtained from Rathburn (Walkerburn, Scotland, UK) and acetic acid from Sigma-Aldrich. Single standard stock solutions were prepared in acetonitrile. Reagent grade MilliQ-water (18.2 M $\Omega$ ) (Millipore, Watford, UK) was used for spikes and preparation of solutions. The working standard solutions were prepared by further diluting the stock standard solutions with acetonitrile/MilliQ-water (50:50 v/v).

\subsection{Analytical procedure}

Frozen sewage sludge was freeze-dried and alkylphenolic compounds were solvent extracted on a multi-reax system (Heidolph Instruments, Schwubach, 
Germany). The sludge samples were extracted using 10ml MeOH/acetone (1:1) and mechanically shaken for half an hour in a $25 \mathrm{ml}$ Teflon tube. This procedure was repeated twice with centrifugation at $1500 \mathrm{~g}$ for $10 \mathrm{~min}$ each time. The combined supernatants were then subjected to clean up by passing through a pre-conditioned $500 \mathrm{mg} / 3 \mathrm{cc}$ silica SPE cartridge (Waters Ltd, Hertfordshire, UK) which was eluted using $10 \%$ acetic acid in $10 \mathrm{ml} \mathrm{MeOH}$ prior to quantification by LC/ESI/MS/MS consisting of an HPLC (Waters Alliance HPLC system 2695) coupled to a Waters Quattro Premier XE mass spectrometer with a Z-Spray ESI source (Micromass, Manchester, UK.) as described previously [8]. For method recovery work freeze-dried sludges were spiked with the alkylphenolic compounds to give final concentrations of $0.125 \mathrm{mg} \mathrm{kg}^{-1}$ (low recovery, LR) or $1.25 \mathrm{mg} \mathrm{kg}^{-1}$ (high recovery, HR) samples.

\section{RESULTS AND DISCUSSION}

\subsection{Method development}

The determination of alkylphenolic compounds in the sewage sludge matrix was established using solvent extraction, clean up with silica solid phase extraction cartridges and quantification using liquid chromatography tandem mass spectrometry in ESI mode (LC/ESI/MS/MS). The method had previously been developed for laboratory generated activated sludge mixed liquor samples without including the carboxylated metabolites employing SPE and LC/ESI/MS [13]. The determination of alkylphenolic compounds in sludge samples was similar to the methodology established for the soluble alkylphenolic compounds in sewages as previously reported in Koh et al., [8].

In order to prevent biotransformation of the long chain alkylphenolic compounds, sludge samples were frozen and freeze-dried following collection. The STW sludge $(0.2 \mathrm{~g})$ was initially extracted with various solvent combinations which included dichloromethane, $\mathrm{MeOH}$ and acetone. The combination of $\mathrm{MeOH}$ and acetone $(10 \mathrm{ml})$ in 1:1 ratio gave a superior recovery, which ranged from $50 \%$ to $90 \%$. This was similar to those reported where recoveries between $64 \%$ to $94 \%$ were obtained using the same solvent combination on river sediments [26].

Two commercially available SPE cartridges, silica and an anion-exchanger $\mathrm{NH}_{2}$, were considered for use in the clean-up step. Commonly used organic solvents 
such as ethyl acetate, hexane, $\mathrm{MeOH}$ and a combination of each of these solvents were evaluated and gave recoveries $>70 \%$ from using silica SPE and elution with neat $\mathrm{MeOH}$. However, the addition of $10 \%$ acetic acid to $\mathrm{MeOH}$ gave the maximum recovery (77-105\%) of alkylphenolic compounds while retaining most interfering coextracted chemicals. A silica SPE clean-up step prior to LC/MS/MS analysis was found to remove further matrix interferences $(7-15 \%)$, which is consistent with other studies using silica based clean up [28, 29]. Following elution of these compounds from the silica SPE, the alkylphenolic compounds were quantified using the LC/MS/MS as shown schematically in Figure 1.

Please insert Figure 1 here.

The optimum LC/MS/MS conditions used for compound identification on sludge samples were reached when the highest intensities or superior signal-to-noise $(\mathrm{S} / \mathrm{N})$ resolution of $>3$ were achieved for each alkylphenolic compound. A chromatogram illustrating the separation can be seen in Figure 2. Calibration standards obtained through linear regression was $r^{2}=0.998$ for AP, APEO and APEC. The instrument variability of the LC/MS/MS was $<5 \%$. Elution times for each compound in solid samples were reproducible (within $\pm 0.2 \mathrm{~min}$ ) which demonstrated the robustness of the liquid chromatography and that addition of ammonium hydroxide did not affect the elution time/interaction of the alkylphenolic compounds (hydrophilic/hydrophobic properties) from the stationary phase of the Gemini C18 column as previously described [8] and confirmed by [30, 31].

Please insert Figure 2 here.

\subsection{Matrix effects}

Subsequent to the evaluation of dry weight of solid samples on alkylphenolic compounds recovery, matrix interference was evaluated for sludge based on a $0.2 \mathrm{~g}$ primary sludge sample (CAS) and a blank using (MQ water) which were unspiked or spiked with the alkylphenolic compounds (low and high spike of $0.125 \mathrm{mg} \mathrm{kg}^{-1}$ and $1.25 \mathrm{mg} \mathrm{kg}^{-1}$ respectively). The signal suppression was derived using the following equation: 
$\frac{A_{s}-\left(A_{s p}-A_{u s p}\right)}{A_{s}} \times 100$

where $A s$ is the peak area of the analyte in pure standard solution, Asp is the peak area in the spiked matrix extract and Ausp is the peak area in the unspiked matrix extract. For the water extract, signal suppression of 6-10\% was observed for all determinands in both low and high spikes. The overall method recoveries decreased by up to $20 \%$ for the high spiked compared to the low spiked sample, thus showing some matrix interferences still persisted. Significantly higher matrix interference was observed for primary and mixed primary and RAS sludge samples of up to $27 \%$ for $\mathrm{AP}_{1-12} \mathrm{EO}$. Greater matrix interference was observed for primary sewage sludge for hydrophilic long chain $\mathrm{AP}_{3-12} \mathrm{EO}$ of up to $27 \%$ and up to $24 \%$ for hydrophobic short chain alkylphenolic metabolites $\mathrm{AP}_{1-2} \mathrm{EO}, \mathrm{AP}_{1-3} \mathrm{EC}$ and $\mathrm{APs}$. The impact of sample size and concentration factors on matrix effects has previously been observed to be of significance in relation to reducing matrix effects in the analysis of alklyphenols [32].

\subsection{Method recovery}

The recoveries and relative standard deviations were determined in experiments where the analytes were in the concentration range of low spike and high spike using MQ water and primary sludge samples. Recoveries ranged from $51 \%$ to $89 \%$ for AP, APEO and APEC for low and high spikes (Figure 3). Generally, the relative standard deviations (RSD) were in the range of 1 to 14. Recoveries for NPEO and OPEO averaged $>70 \%$ with an RSD of 5 and 3 respectively for high spiked MQ water.

Please insert Figure 3 here.

Recoveries for NPEO and OPEO were $76 \%$ and $75 \%$ with an RSD of 6 and 5 respectively for low spiked sludge. Approximately $<3 \%$ recovery values were observed for high spiked sludge compared to the low spiked sludge with low RSD (2 - 10) obtained for the long-chain $\mathrm{AP}_{3-12} \mathrm{EO}\left(\mathrm{NP}_{3-12} \mathrm{EO}\right.$ and $\left.\mathrm{OP}_{3-12} \mathrm{EO}\right)$. This methodology exhibits consistent recoveries and low RSD for primary sludge samples. 
The method recovery for sludge samples was on a par with or slightly lower for $\mathrm{NP}_{1-12} \mathrm{EO}$ and $\mathrm{OP}_{1-12} \mathrm{EO}$ which averaged $76 \%$ and $73 \%$ compared to a study performed on $\mathrm{NP}_{3-15} \mathrm{EO}(78 \%)$ and $\mathrm{OP}_{3-15} \mathrm{EO}$ (80\%) [24]. Nonylphenol recovery observed in this study of $70 \%$ and $73 \%$ compared well with that reported previously [24]. In contrast, lower recovery was observed in this study for OP which was $63 \%$ (Figure 3) in comparison to $75 \%$ [24]. Higher recovery values were obtained in this study for the carboxylated species at $72 \%$ and $73 \%$ compared to $61 \%$ and $65 \%$ for $\mathrm{NP}_{1} \mathrm{EC}$ and $\mathrm{OP}_{1} \mathrm{EC}$ respectively in Petrovic et al. [33].

\subsection{Method detection limit}

Method detection limit (MDL) was determined by subjecting the entire analytical extraction and detection procedure to evaluation using $0.2 \mathrm{~g}$ sludge samples. The MDL determined for the entire SPE and LC/MS/MS method ranged from 6 to 60 $\mu \mathrm{g} \mathrm{kg}{ }^{-1}$ for AP, APEO and APEC (Table 2). Generally, lower MDLs were achieved for nonylphenol compounds compared to the octylphenol analogues.

Please insert Table 2 here.

A comparison of this method (Table 2) with other methodologies based on MDL indicates that sensitivity was equivalent to other methods, with the exception of $\mathrm{NP}$ and $\mathrm{NP}_{1} \mathrm{EC}$ [34]. The MDL for $\mathrm{NP}$ and $\mathrm{NP}_{1} \mathrm{EC}$ in this study were $11 \mu \mathrm{g} \mathrm{kg}^{-1}$ $(\mathrm{RSD}=5 \%)$ and $12 \mu \mathrm{g} \mathrm{kg}^{-1}(\mathrm{RSD}=2 \%)$ respectively whilst corresponding MDL of 0.5 $\mu \mathrm{g} \mathrm{kg}{ }^{-1}$ and $1.5 \mu \mathrm{g} \mathrm{kg}^{-1}$ were obtained by Petrovic et al [34]. However, these RSD values of $5 \%$ and $2 \%$ were lower in comparison to Petrovic et al., [34] at $9 \%$ and $8 \%$ respectively for $\mathrm{NP}$ and $\mathrm{NP}_{1} \mathrm{EC}$. At present, the high concentrations of APEOs commonly found in sludge imply that the current detection method is sensitive enough and achieves a higher degree of accuracy and reliability in terms of RSD in comparison to other reported methods (Table 2). This could be a direct result of using smaller sample size than those commonly employed of $2 \mathrm{~g}$ for sewage sludges. The significance of sample size on method performance has been previously demonstrated in sewage sludge and it was observed that minimising sample size reduces matrix interferences and gives low RSD [32].

\subsection{Application to sludge samples}


To test the validity of the method, alkylphenolic compounds in primary sludges, primary and surplus activated sludge mixed sludges, return activated sludge (RAS) and drum thickener sludge liquors from both CAS and N/DN and N/DN-P configurations were analyzed. There were varying concentrations of alkylphenolic compounds in the primary and mixed sludges from the CAS and the concentrations were much lower than in RAS and drum thickener sludge liquors. There appears to have been some biodedegradation in the sewerage system which could account for the high concentration of $\mathrm{NP}_{2} \mathrm{EC}$ at $26515 \mu \mathrm{g} \mathrm{kg}^{-1}$ in CAS (Table 3)

Please insert Table 3 here.

Nonylphenolic compounds were 2-3 fold higher in concentration compared to their octyl analogues. The estrogenic non-ionic surfactant metabolite by-product NP and OP were found in the various sludge samples. Octylphenol was below the MDL detection limit in a number of samples up to a maximum of $237 \mu \mathrm{g} \mathrm{kg}^{-1}$ in the drum thickener sludge liquors (Table 3). Nonylphenol existed in the return activated sludge in both the N/DN-P and N/DN at $2087 \mu \mathrm{g} \mathrm{kg}^{-1}$ and $6696 \mu \mathrm{g} \mathrm{kg}^{-1}$ respectively but $<1920 \mu \mathrm{g} \mathrm{kg}^{-1}$ for primary sludge, mixed sludge and drum thickener sludge liquors Since most of these compounds, due to their physiochemical properties, may preferentially bind to the sludge particulates, removal of these solids will improve the removal efficiency for these compounds $[35,36]$. Furthermore, the implication of this finding is that sedimentation will result in the accumulation of the non-polar hydrophobic AP and short chain APEO in sludge and have further repercussions for sludge treatment and re-use. In the majority of the STWs, there were significant amounts of $\mathrm{NP}_{1-2} \mathrm{EC}$ compared to $\mathrm{OP}_{1-2} \mathrm{EC}$ in the RAS of the N/DN and N/DN-P works. The carboxylated products $\left(\mathrm{AP}_{1-3} \mathrm{EC}\right)$ were present in relatively high concentrations in the RAS $\left(\mathrm{NP}_{1-2} \mathrm{EC}=1978-4673 \mu \mathrm{g} \mathrm{kg}^{-1}, \mathrm{OP}_{1-2} \mathrm{EC}=<\mathrm{LOD}-53 \mu \mathrm{g} \mathrm{Kg}^{-1}\right)$ and were not necessarily efficiently removed during activated sludge wastewater treatment [37].

Since the voluntary agreement to withdraw the use of these non-ionic surfactants and also the replacement to alcohol ethoxylates, worldwide concentration of APEOs and subsequently APECs have declined, as reflected by the 2 to 3 order of magnitude decrease of NPEC (highest concentration $2.4 \mu \mathrm{g}^{-1}$ ) in the STW effluent 
discharging into River Schelde, Belgium [31]. In a recent study in Spain, NP showed a 10-fold decrease in concentration over the last 5 years [38]. This phenomenon was similarly observed in a recent assessment of alkylphenolic compounds in various UK sewage treatment works [39].

\section{CONCLUSIONS}

A solvent extraction followed by liquid chromatography tandem mass spectrometry was developed to determine non-ionic surfactant, alkylphenol polyethoxylates and their metabolites alkylphenoxy carboxylates and alkyphenols with high efficiency in sludge. These compounds were concentrated and extracted by methanol/acetone $(1: 1 \mathrm{v} / \mathrm{v})$ in sludge, and extracts were cleaned up by silica solid phase extraction proceeding determination by liquid chromatography tandem mass spectrometry using analytical standards for quantification. The recovery for these target compounds, determined by spiking sewage sludge at two concentrations ranged from $50 \%$ to $89 \%$ with method detection limit from $6 \mu \mathrm{g} \mathrm{kg}^{-1}$ to $60 \mu \mathrm{g} \mathrm{kg}^{-1}$. The methodology was subsequently applied to sludge samples obtained from a carbonaceous activated sludge plant, a nitrifying/denitrifying activated sludge plant and a nitrifying/denitrifying activated sludge plant with phosphorus removal. The nonylphenolic compounds were 2-3 fold higher in concentration compared to the octyl analogues. The estrogenic metabolite nonylphenol was present at concentrations ranging from $336 \mu \mathrm{g} \mathrm{kg}^{-1}$ to $6696 \mu \mathrm{g} \mathrm{kg}^{-1}$. The assessment of the various sludges from the sewage treatment works established that carboxylated products $\left(\mathrm{AP}_{1-3} \mathrm{EC}\right)$ were present in relatively high concentrations in the RAS $\left(\mathrm{NP}_{1-2} \mathrm{EC}=1978-4673 \mu \mathrm{g} \mathrm{kg}^{-1}\right.$, $\mathrm{OP}_{1-2} \mathrm{EC}=<\mathrm{LOD}-53 \mu \mathrm{g} \mathrm{kg}^{-1}$ ) probably due to recirculation in the system.

\section{ACKNOWLEDGEMENT}

One of the authors (Y.K.K. Koh) is grateful to the Public Utilities Board of Singapore for the award of a $\mathrm{PhD}$ scholarship. The authors would like to thank the following companies: Thames Water and Yorkshire Water for providing their support and funding and Dan McMillan at Waters Ltd. for analytical support.

\section{REFERENCES}


1. N.D. Bedding, A.E. McIntyre, R. Perry, and J.N. Lester, Organic contaminants in the aquatic environment. I. sources and occurrence. Sci. Total Environ. 25 (1982), pp 143-167.

2. W. Giger, P.H. Brunner, and C. Schaffner, 4-Nonylphenol in Sewage-Sludge Accumulation of Toxic Metabolites from Nonionic Surfactants. Science 225 (1984), pp 623-625.

3. S. Jobling, D. Sheahan, J.A. Osborne, P. Matthiessen, and J.P. Sumpter, Inhibition of testicular growth in rainbow trout (Oncorhynchus mykiss) exposed to estrogenic alkylphenolic chemicals. Environ. Toxicol. Chem. 15 (1996), pp 194-202.

4. K.M. Lai, M.D. Scrimshaw, and J.N. Lester, The effects of natural and synthetic steroid estrogens in relation to their environmental occurrence. Crit. Revs. Toxicol. 32 (2002), pp 113-132.

5. A. Soares, E. Cartmell, J.N. Lester, and B. Guieysse, Nonylphenol its occurrence and fate in the environment: A critical review of environ effects. Environ. Int. 34 (2008), pp 1033-1049.

6. K. Koh, T.Y. Chiu, A.R. Boobis, E. Cartmell, J.N. Lester, and M.D. Scrimshaw, Determination of steroid estrogens in wastewater by high performance liquid chromatography-tandem mass spectrometry. J. Chromatogr. A, 1173 (2007), pp 81-87.

7. T.Y. Chiu, N. Paterakis, M.D. Scrimshaw, E. Cartmell, and J.N. Lester, $A$ critical review of the formation of mono and dicarboxylated metabolic intermediates of alkyphenol polyethoxylates in the activated sludge process. Crit. Revs. Environ. Sci. Technol. (in press).

8. Y.KK. Koh, T.Y. Chiu, A.R. Boobis, E. Cartmell E., S.J.T. Pollard, M.D. Scrimshaw and J.N. Lester, A sensitive and robust method for the determination of alkylphenol polyethoxylates and their carboxylic acids and their transformation in a trickling filter wastewater treatment plant. Chemosphere 73 (2008), pp 551-556.

9. Y.K.K. Koh, J.N. Lester, and M.D. Scrimshaw, The Fate and Behaviour of Alkylphenols and their Poly-ethoxylates in an Activated Sludge Plant. Bull. Environ. Contam. Toxicol. 75 (2005), pp 1098-1106. 
10. J.E. Loyo-Rosales, C.P. Rice, and A. Torrents, Fate of octyl-and nonylphenol ethoxylates and some carboxylated derivatives in three American wastewater treatment plants. Environ. Sci. Technol. 41 (2007), pp 6815-6821.

11. M. Ahel, E. Molnar, S. Ibric, and W. Giger, Estrogenic metabolites of alkylphenol polyethoxylates in secondary sewage effluents and rivers. Water Sci. Technol. 42 (2000), pp 15-22.

12. K.H. Langford, M.D. Scrimshaw, J. Birkett, and J.N. Lester, Degradation of nonylphenolic surfactants in activated sludge batch tests. Water Res. 39 (2005), pp 870-876.

13. K.H. Langford, M.D. Scrimshaw, J. Birkett, and J.N. Lester, The partitioning of alkylphenolic surfactants and polybrominated diphenyl ether flame retardants in activated sludge batch tests. Chemosphere 61 (2005), pp 12211230.

14. K.H. Langford, M.D. Scrimshaw, and J.N. Lester. The impact of process variables on the removal of PBDEs and NPEDs during biological sewage treatment. Arch Environ. Contam. Toxicol. 53 (2007), pp 1-7.

15. O.A.H. Jones, P. Green, N. Voulvoulis, and J.N. Lester, Questioning the excessive use of advanced treatment to remove organic micropollutants from wastewater. Environ. Sci. Technol. 41 (2007), pp 5085-5089.

16. J.E. Loyo-Rosales, I. Schmitz-Afonso, C.P. Rice, and A. Torrents, Analysis of octyl- and nonylphenol and their ethoxylates in water and sediments by liquid chromatography/tandem mass spectrometry. Anal. Chem. 75 (2003), pp 48114817.

17. M.D. Scrimshaw, K.H. Langford, and J.N. Lester, Analytical methods for the determination of alkylphenolic surfactants and polybrominated diphenyl ethers in wastewaters and sewage sludges. I a review of methodologies. Environ. Technol. 25 (2004), pp 961-974.

18. K.H. Langford, M.D. Scrimshaw, and J.N. Lester, Analytical methods for the determination of alkylphenolic surfactants and polybrominated diphenyl ethers in wastewaters and sewage sludges. II method development. Environ. Technol. 25 (2004), pp 975-985. 
19. R. Gibson, M.J. Wang, E. Padgett, and A.J. Beck, Analysis of 4-nonylphenols, phthalates, and polychlorinated biphenyls in soils and biosolids. Chemosphere 61 (2005), pp 1336-1344.

20. J.E. Loyo-Rosales, C.P. Rice, and A. Torrents, Octyl and nonylphenol ethoxylates and carboxylates in wastewater and sediments by liquid chromatography/tandem mass spectrometry. Chemosphere 68 (2007), pp 2118-2127.

21. R.L. Gomes, E. Avcioglu, M.D. Scrimshaw, and J.N. Lester, Analysis of soil, sediment and sludge. Steroid estrogen determination in sediment and sewage sludge: a critique of chromatographic/mass spectrometry methods incorporating a case study in method development. Tr. Anal. Chem. 3 (2004), pp 737-744.

22. R.S.K. Buisson, P.W.W. Kirk, and J.N. Lester, Determination of chlorinated phenols in water, wastewater and wastewater sludge. Chromatogr. Sci. 22 (1984), pp 339-342.

23. A.M. Robertson, and J.N. Lester, Supercritical fluid extraction of s-triazines and phenylurea herbicides from sediment. Environ. Sci. and Technol. 28 (1994), pp 346-351.

24. M. Petrovic, A. Diaz, F. Ventura, and D. Barcelo', Simultaneous determination of halogenated derivatives of alkylphenolethoxylates and their metabolites in sludges, river sediments, surface, drinking and waste waters by liquid chromatography-mass spectrometry. Anal. Chem. 73 (2001), pp 58865895.

25. D.Y. Shang, R.W. Macdonald, and M.G. Ikonomou, Persistence of nonylphenol ethoxylate surfactants and their primary degradation products in sediments from near a municipal outfall in the strait of Georgia, British Columbia, Canada. Environ. Sci. Technol. 33 (1999), pp 1366-1372.

26. M. Petrovic, S. Lacorte, P. Viana, and D. Barcelo', Pressurized liquid extraction followed by liquid chromatography-mass spectrometry for the determination of alkylphenolic compounds in river sediment. J. Chromatogr. A 959 (2002), pp 15-23. 
27. N. Jonkers, R.W.P.M. Laane, and P. de Voogt, Fate of nonylphenol ethoxylates and their metabolites in two Dutch estuaries: Evidence of biodegradation in the field. Environ. Sci. Technol. 37 (2003), pp321-327.

28. E.R. Bennett, and C.D. Metcalfe, Distribution of degradation products of alkylphenol ethoxylates near sewage treatment plants in the lower Great Lakes, North America. Environ. Toxicol. Chem. 19 (2000), pp 784-792.

29. H.B. Lee, and T.E. Peart, Determination of 4-Nonylphenol in Effluent and Sludge from Sewage-Treatment Plants. Anal. Chem. 67 (1995), pp 1976-1980.

30. N. Jonkers, and P. de Voogt, Methods for the sample handling of nonionic surfactants in sludges and sediments. T.P. Knepper, D. Barceló, and P. de Voogt, eds., Analysis and Fate of Surfactants in the Aquatic Environment, Elsevier, Amsterdam, The Netherlands, 2003, pp 415--428.

31. R. Loos, G. Hanke, G. Umlauf, and S.J. Eisenreich, LC-MS-MS analysis and occurrence of octyl- and nonylphenol, their ethoxylates and their carboxylates in Belgian and Italian textile industry, waste water treatment plant effluents and surface waters. Chemosphere 66 (2007), pp 690-699.

32. T.Y. Chiu, Y.K.K. Koh, N. Paterakis, A.R. Boobis, E. Cartmell, K.H. Richards, J.N. Lester, and M.D. Scrimshaw, The significance of sample mass in the analysis of steroids estrogens in sewage sludge and the derivation of partition coefficients in wastewaters. J. Chromatogr. A, 1216(24), pp 4923-4926.

33. M. Petrovic, and D. Barcelo', Analysis of ethoxylated nonionic surfactants and their metabolites by liquid chromatography/atmospheric pressure ionization mass spectrometry. J. Mass. Spectrom. 36 (2001), pp 1173-1185.

34. M. Petrovic, D. Barcelo', A. Diaz, and F. Ventura, Low nanogram per liter determination of halogenated nonylphenols, nonylphenol carboxylates, and their non-halogenated precursors in water and sludge by liquid chromatography electrospray tandem mass spectrometry. J. Am. Soc. Mass Spectrom. 14 (2003), pp 516-527.

35. M. Esperanza, M.T. Suidan, F. Nishimura, Z.M Wang, G.A. Sorial, A. Zaffiro, P. McCauley, R. Brenner, and G. Sayles, Determination of sex hormones and nonylphenol ethoxylates in the aqueous matrixes of two pilot-scale municipal wastewater treatment plants. Environ. Sci. Technol. 38 (2004), pp 3028-3035.

36. T. Isobe, H. Nishiyama, A. Nakashima, and H. Takada, Distribution and behavior of nonylphenol, octylphenol, and nonylphenol monoethoxylate in 
Tokyo metropolitan area: Their association with aquatic particles and sedimentary distributions. Environ. Sci. Technol. 35 (2001), pp1041-1049.

37. G.G. Ying, B. Williams, and R. Kookana, Environmental fate of alkylphenols and alkylphenol ethoxylates - A review. Environ. Int. 28 (2002), pp 215-226.

38. S. Gonzalez, M. Petrovic, and D. Barceló, Simultaneous extraction and fate of linear alkylbenzene sulfonates, coconut diethanol amides, nonylphenol ethoxylates and their degradation products in wastewater treatment plants, receiving coastal waters and sediments in the Catalonian area (NE Spain), J. Chromatogr. A 1052 (2004), pp 111-120.

39. Y.K.K. Koh, An evaluation of the factors controlling biodegradation of endocrine disrupting chemicals during wastewater treatment, Ph.D. diss., Imperial College London, 2008.

40. V. Andreu, E. Ferrer, J.L. Rubio, G. Font, and Y. Picó, Quantitative determination of octylphenol, nonylphenol, alkylphenol ethoxylates and alcohol ethoxylates by pressurized liquid extraction and liquid chromatography-mass spectrometry in soils treated with sewage sludges. Sci. Total Environ. 378(1-2) (2007), pp 124-129.

41. R. Céspedes, S. Lacorte, A. Ginebreda, and D. Barceló, Occurrence and fate of alkylphenols and alkylphenol ethoxylates in sewage treatment plants and impact on receiving waters along the Ter River (Catalonia, NE Spain). Environ. Pollut. 153(2) (2008), pp 384-392. 
$0.2 \mathrm{~g}$ Sludge

Freeze-dried

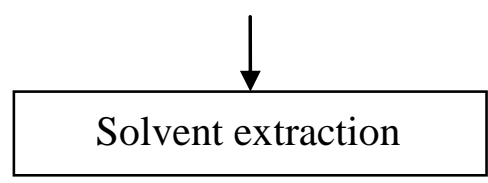

$10 \mathrm{ml} \mathrm{MeOH/Acetone}(1: 1 \mathrm{v} / \mathrm{v})(2 x)$

Shake $1 / 2$ h each time

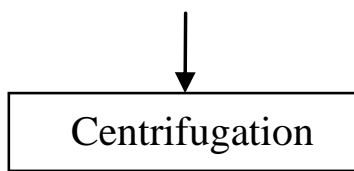

$1500 \mathrm{~g}$ for $10 \mathrm{~min}$

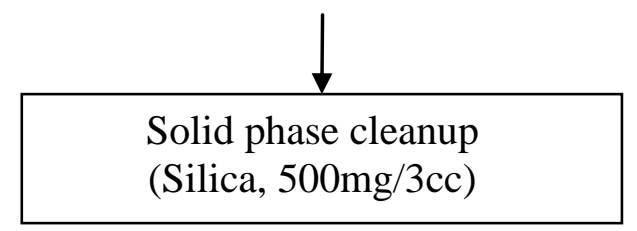

Elute $10 \%$ Acetic acid in $\mathrm{MeOH} 10 \mathrm{ml}$

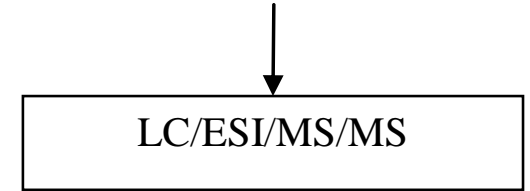

50 min run time

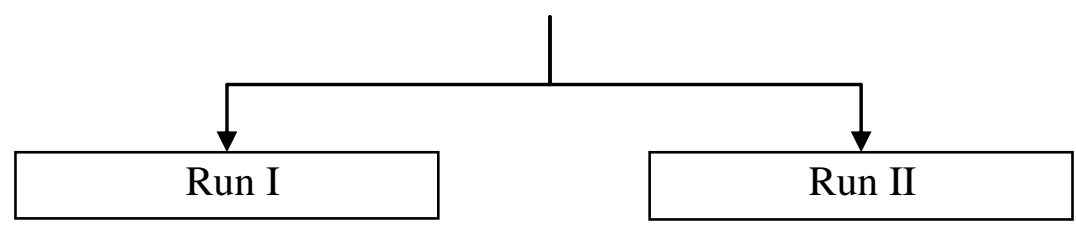

$\mathrm{NP}_{3-12} \mathrm{EO}$ and $\mathrm{OP}_{3-12} \mathrm{EO}$

$\mathrm{NP}, \mathrm{NP}_{1-2} \mathrm{EO}, \mathrm{NP}_{1-3} \mathrm{EC}$, OP, $\mathrm{OP}_{1-2} \mathrm{EO}, \mathrm{OP}_{1-3} \mathrm{EC}$

Figure 1. Scheme of the analytical method for extraction and determination of alkylphenolic compounds in sewage sludge. 


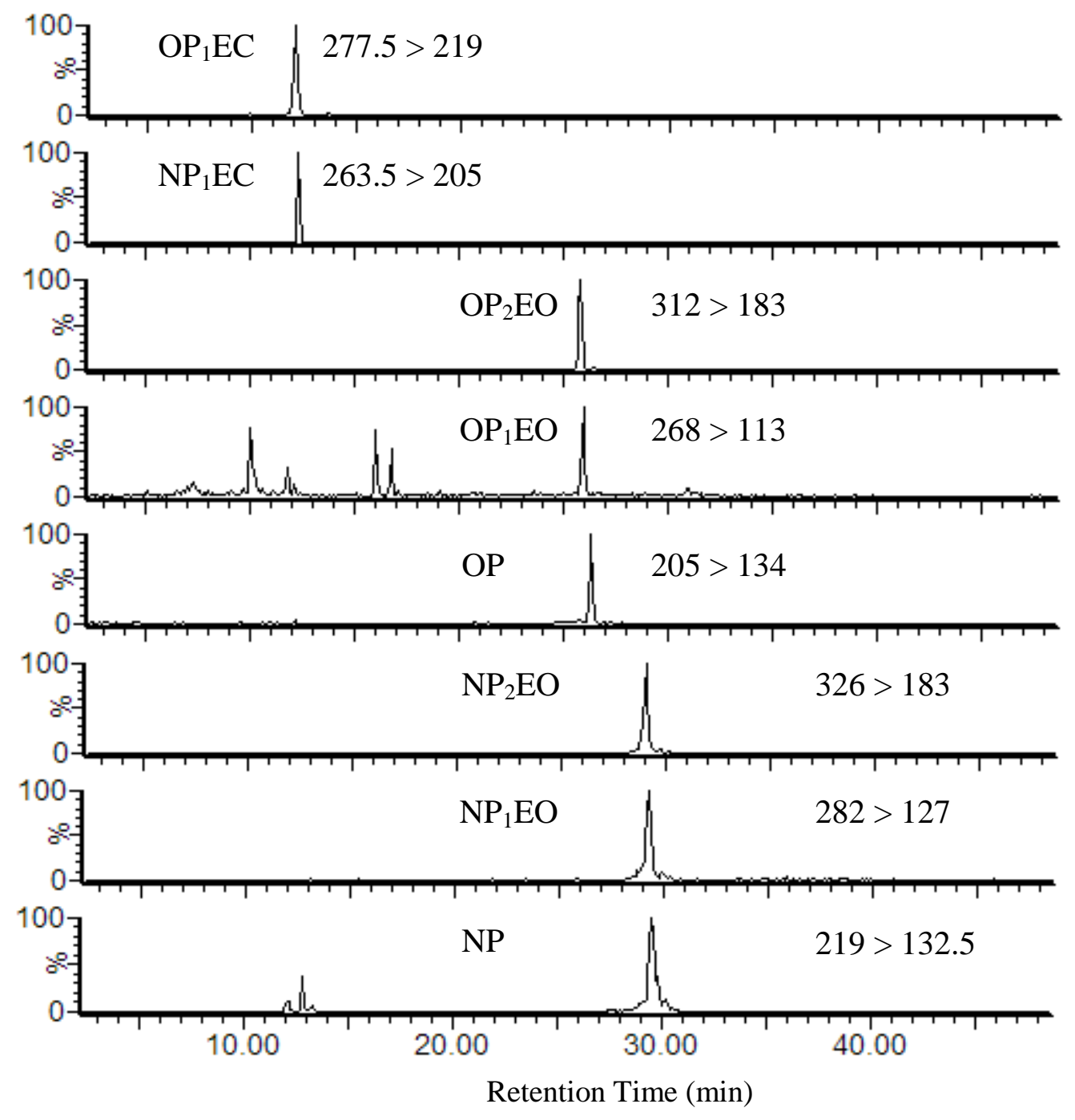

Figure 2. LC/MS/MS mass spectra of alkyphenolic compounds in $0.2 \mathrm{~g} \mathrm{dwt}$ primary sludge sample spiked at $1.25 \mu \mathrm{g} \mathrm{g}^{-1}$ (only one product ion for each alkylphenolic oligomer is shown). 
$\square \mathrm{MQ}$ Water (Low Spike) $\square \mathrm{MQ}$ Water (High Spike) $\square$ Sludge (Low Spike) $\boxminus$ Sludge (High Spike)

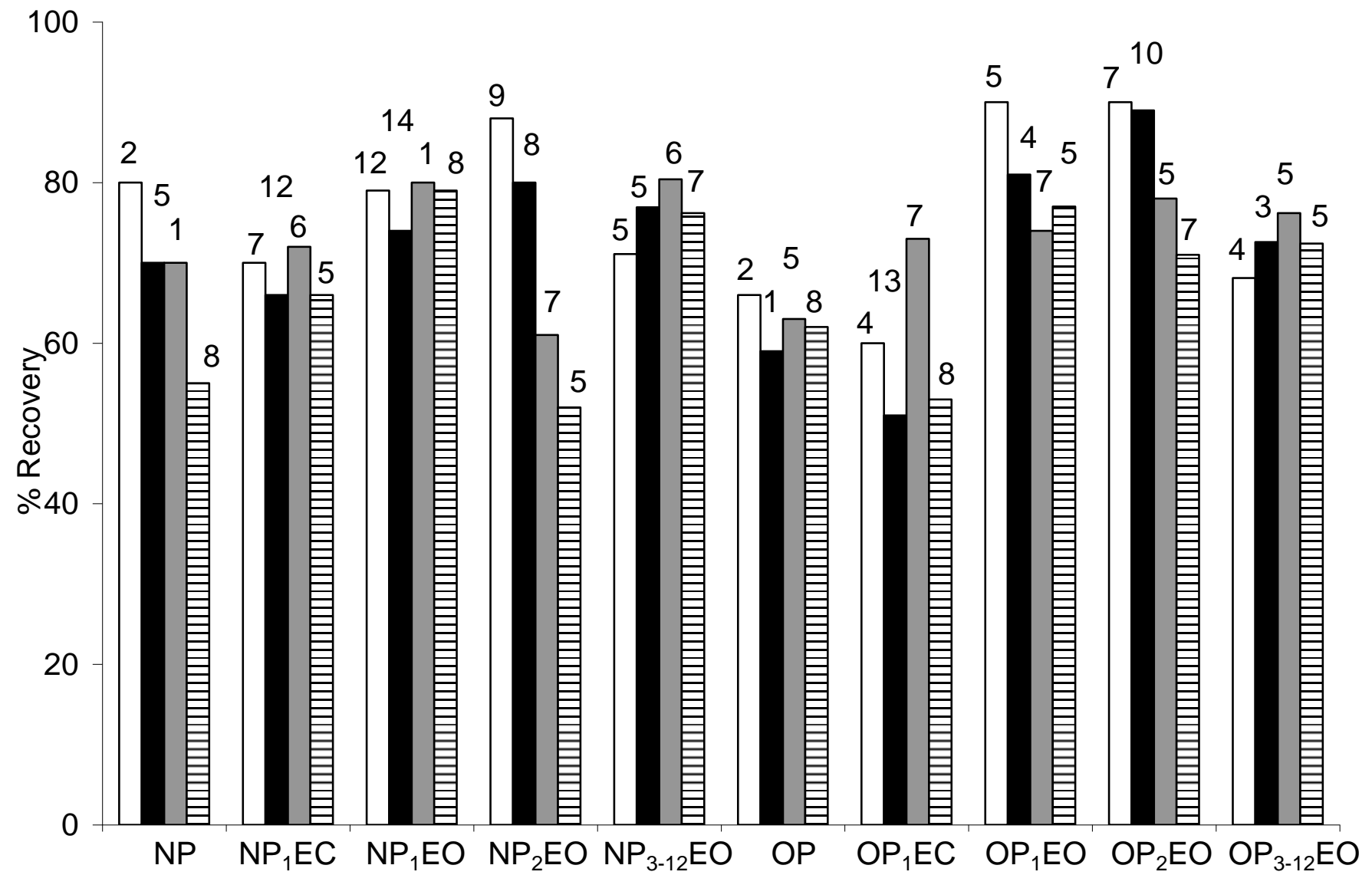

Figure 3. Method recoveries (\%) and relative standard deviations (number at the top of each bar in \%) in reagent water (MQ water) and primary sewage sludge $(n=3)$ Data based on spiking at $0.125 \mathrm{mg} \mathrm{kg}^{-1}$ (low spike) and $1.25 \mathrm{mg} \mathrm{kg}^{-1}$ (high spike) of APs, $\mathrm{AP}_{1} \mathrm{EC}, \mathrm{AP}_{1-2} \mathrm{EOs}$ and $\mathrm{AP}_{3-12} \mathrm{EOs}$. 
Table 1 Description of the sludge samples taken from each sewage treatment works

\begin{tabular}{|l|l|l|l|l|}
\hline & Primary Sludge & $\begin{array}{l}\text { Primary and Surplus } \\
\text { Activated sludge (mixed) }\end{array}$ & Return Activated Sludge & $\begin{array}{l}\text { Drum thickener primary } \\
\text { sludge liquors }\end{array}$ \\
\hline $\begin{array}{l}\text { CAS } \\
\text { Sample A (April 2007) } \\
\text { and Sample B (April 2008) }\end{array}$ & $\checkmark$ & $\checkmark$ & $\mathbf{x}$ & $\mathbf{x}$ \\
\hline N/DN & $\checkmark$ & $\mathbf{x}$ & $\checkmark$ & $\mathbf{x}$ \\
\hline N/DN-P & $\checkmark$ & $\mathbf{x}$ & $\checkmark$ & $\checkmark$ \\
\hline
\end{tabular}

Note - CAS - Carbonaceous activated sludge plant; N/DN - nitrifying/denitrifying activated sludge plant; N/DN-P nitrifying/denitrifying with phosphorus removal activated sludge plant 
Table 2. A summary of various analytical procedures for the analysis of alkylphenolic compounds in sewage sludge matrices.

\begin{tabular}{|c|c|c|c|c|}
\hline Compound & Extraction & Detection method & MDL & Reference \\
\hline $\begin{array}{l}\mathrm{NP}, \mathrm{OP}, \mathrm{NP}_{1-15} \mathrm{EO}, \\
\mathrm{OP}_{1-15} \mathrm{EO}, \mathrm{NP}_{1-2} \mathrm{EC}, \\
\mathrm{OP}_{1-2} \mathrm{EC}\end{array}$ & $\begin{array}{c}\mathrm{C}_{18} \text { SPE extraction; clean } \\
\text { up by sonication }\end{array}$ & LC/ESI/MS & $5-25 \mu \mathrm{g} \mathrm{kg}^{-1}$ & $\begin{array}{c}\text { Petrovic et al., } 2001 \\
\text { [24] }\end{array}$ \\
\hline $\begin{array}{l}\mathrm{NP} \\
\mathrm{NP}, \mathrm{OP}\end{array}$ & $\begin{array}{c}\text { Pressurized liquid } \\
\text { extraction; clean up by } \\
\mathrm{C}_{18} \text { SPE }\end{array}$ & LC/ESI/MS & $\begin{array}{c}0.3-1 \mu \mathrm{g} \mathrm{kg}^{-1} \\
(\mathrm{OPEOs} \& \text { NPEOs }) \\
30 \mu \mathrm{gg}^{-1} \text { (OP \& NP) }\end{array}$ & $\begin{array}{l}\text { *Andreu et al. } \\
2007[40]\end{array}$ \\
\hline $\mathrm{OP}, \mathrm{NP}, \mathrm{NP}_{1-15} \mathrm{EO}$ & $\begin{array}{l}\text { Pressurized liquid } \\
\text { extraction }\end{array}$ & LC/ESI/MS & 5 to $23 \mathrm{mg} \mathrm{kg}^{-1}$ & $\begin{array}{l}\text { Cespedes et al., } \\
2008[41]\end{array}$ \\
\hline $\begin{array}{l}\mathrm{NP}, \mathrm{NP}_{1-2} \mathrm{EC}, \mathrm{XAP}_{1-} \\
{ }_{2} \mathrm{EC}\end{array}$ & $\begin{array}{c}\text { Pressurized liquid } \\
\text { extraction; clean up by } \\
\mathrm{C}_{18} \text { SPE }\end{array}$ & LC/ESI/MS/MS & $\begin{array}{c}0.5 \mu \mathrm{g} \mathrm{kg}^{-1}(\mathrm{NP}) \\
1.5 \mu \mathrm{g} \mathrm{kg}^{-1}\left(\mathrm{NP}_{1-2} \mathrm{EC}\right)\end{array}$ & $\begin{array}{c}\text { Petrovic et al., } 2003 \\
\text { [34] }\end{array}$ \\
\hline $\begin{array}{l}\mathrm{OP}, \mathrm{NP}, \mathrm{NP}_{1-12} \mathrm{EO}, \\
\mathrm{OP}_{1-12} \mathrm{EO}, \mathrm{NP}_{1-2} \mathrm{EC}, \\
\mathrm{OP}_{1-2} \mathrm{EC}\end{array}$ & $\begin{array}{c}\text { Solvent extraction; clean } \\
\text { up by silica SPE }\end{array}$ & LC/ESI/MS/MS & $\begin{array}{c}\# 11 \mathrm{\mu g} \mathrm{kg}^{-1}(\mathrm{NP}) \\
12 \mu \mathrm{g} \mathrm{kg}^{-1}\left(\mathrm{NP}_{1} \mathrm{EC}\right) \\
6 \mu \mathrm{g} \mathrm{kg}^{-1}\left(\mathrm{NP}_{1} \mathrm{EO}\right) \\
12 \mu \mathrm{g} \mathrm{kg}^{-1}\left(\mathrm{NP}_{2} \mathrm{EO}\right) \\
7 \mu \mathrm{gg}^{-1}\left(\mathrm{NP}_{3-12} \mathrm{EO}\right) \\
34 \mu \mathrm{g} \mathrm{kg}^{-1}(\mathrm{OP}) \\
60 \mu \mathrm{g} \mathrm{kg}^{-1}\left(\mathrm{OP}_{1} \mathrm{EC}\right) \\
48 \mu \mathrm{g} \mathrm{kg}^{-1}\left(\mathrm{OP}_{1} \mathrm{EO}\right) \\
25 \mu \mathrm{g} \mathrm{kg}^{-1}\left(\mathrm{OP}_{2} \mathrm{EO}\right) \\
8 \mu \mathrm{g} \mathrm{kg}^{-1}\left(\mathrm{OP}_{3-12} \mathrm{EO}\right)\end{array}$ & This study, 2009 \\
\hline
\end{tabular}

Note: * Methodology was based on soil sample amended with $10 \%$ sewage sludge; \# Method detection limit of alkylphenolic compounds in freeze-dried $0.2 \mathrm{~g}$ dwt primary digested sludge $(n=3)$. 
Table 3. Concentrations of alkylphenolic compounds in the sewage sludge samples from various STWs.

\begin{tabular}{|c|c|c|c|c|c|c|c|c|c|}
\hline \multirow[b]{2}{*}{$\begin{array}{l}\text { Alkylphenolic } \\
\text { compounds } \\
\left(\mu \mathrm{g} \mathrm{kg}^{-1} \mathrm{dwt}\right)\end{array}$} & \multicolumn{4}{|c|}{ CAS } & \multicolumn{2}{|c|}{ N/DN } & \multicolumn{3}{|c|}{ N/DN-P } \\
\hline & $\begin{array}{c}\text { Primary } \\
\text { Sludge } \\
\text { (Sample A) } \\
(n=5)\end{array}$ & $\begin{array}{c}\text { Primary and } \\
\text { SAS Mixed } \\
\text { (Sample A) } \\
\quad(n=5)\end{array}$ & $\begin{array}{l}\text { Primary Sludge } \\
\text { (Sample B) } \\
(n=5)\end{array}$ & $\begin{array}{c}\text { Primary SAS } \\
\text { Mixed } \\
(\text { Sample B) } \\
(n=5)\end{array}$ & $\begin{array}{l}\text { Primary } \\
\text { sludge } \\
(n=3)\end{array}$ & $\begin{array}{c}\text { RAS } \\
(n=4)\end{array}$ & $\begin{array}{l}\text { Primary } \\
\text { Sludge } \\
(n=4)\end{array}$ & $\begin{array}{c}\text { RAS } \\
(n=4)\end{array}$ & $\begin{array}{c}\text { Drum } \\
\text { thickener } \\
\text { liquors } \\
(n=4)\end{array}$ \\
\hline $\mathrm{NP}$ & $\begin{array}{c}304 \\
(210-384)\end{array}$ & $\begin{array}{c}157 \\
(24-385)\end{array}$ & $\begin{array}{c}232 \\
(143-368)\end{array}$ & $\begin{array}{c}133 \\
(50-209)\end{array}$ & $\begin{array}{c}378 \\
(216-688)\end{array}$ & $\begin{array}{c}6696 \\
(4682-12093)\end{array}$ & $\begin{array}{c}1307 \\
(529-1652)\end{array}$ & $\begin{array}{c}2087 \\
(1572-2579)\end{array}$ & $\begin{array}{c}1920 \\
(551-3853)\end{array}$ \\
\hline $\mathrm{NP}_{1} \mathrm{EC}$ & $\begin{array}{c}13 \\
(12-14)\end{array}$ & $\begin{array}{c}62 \\
(26-107)\end{array}$ & $<\mathrm{LOD}$ & $\begin{array}{c}28 \\
(14-40)\end{array}$ & $<$ LOD & $\begin{array}{c}3318 \\
(1801-6864)\end{array}$ & $\begin{array}{c}20 \\
(<\mathrm{LOD}-35)\end{array}$ & $\begin{array}{c}2044 \\
(674-2916)\end{array}$ & $\begin{array}{c}38 \\
(13-54)\end{array}$ \\
\hline $\mathrm{NP}_{2} \mathrm{EC}$ & $\begin{array}{c}26515 \\
(9644-89527)\end{array}$ & $\begin{array}{c}241449 \\
(201265-289544)\end{array}$ & $<\mathrm{LOD}$ & $\begin{array}{c}37 \\
(23-45)\end{array}$ & $\begin{array}{c}585 \\
(223-1128)\end{array}$ & $\begin{array}{c}4673 \\
(3564-5763)\end{array}$ & $\begin{array}{c}121 \\
(43-185)\end{array}$ & $\begin{array}{c}1978 \\
(674-3252)\end{array}$ & $\begin{array}{c}506 \\
(126-778)\end{array}$ \\
\hline $\mathrm{NP}_{1} \mathrm{EO}$ & $\begin{array}{c}1950 \\
(1138-2975)\end{array}$ & $\begin{array}{c}1565 \\
(987-2259)\end{array}$ & $\begin{array}{c}14981 \\
(14237-15889)\end{array}$ & $\begin{array}{c}89533 \\
(68558-102689)\end{array}$ & $\begin{array}{c}309 \\
(300-325)\end{array}$ & $\begin{array}{c}4377 \\
(1904-7844)\end{array}$ & $\begin{array}{c}296 \\
(137-427)\end{array}$ & $\begin{array}{c}2812 \\
(2022-3701)\end{array}$ & $\begin{array}{c}1590 \\
(452-2752)\end{array}$ \\
\hline $\mathrm{NP}_{2} \mathrm{EO}$ & $\begin{array}{c}197 \\
(112-269)\end{array}$ & $\begin{array}{c}110 \\
(73-175)\end{array}$ & $\begin{array}{c}61 \\
(29-117)\end{array}$ & $\begin{array}{c}47 \\
(30-67)\end{array}$ & $\begin{array}{c}81 \\
(47-133)\end{array}$ & $\begin{array}{c}8995 \\
(4489-20264)\end{array}$ & $\begin{array}{c}87.4 \\
(30-139)\end{array}$ & $\begin{array}{c}2035 \\
(1741-2583)\end{array}$ & $\begin{array}{c}2536 \\
(1445-4299)\end{array}$ \\
\hline $\mathrm{NP}_{3-12} \mathrm{EO}$ & 154 & 75 & 135 & 70 & $2702 *$ & 11754 & 698 & 1144 & 2311 \\
\hline $\mathrm{OP}$ & $\begin{array}{c}35 \\
(35-36)\end{array}$ & $\begin{array}{c}35 \\
(34-38)\end{array}$ & $\begin{array}{c}35 \\
(34-36)\end{array}$ & $\begin{array}{c}60 \\
(48-69)\end{array}$ & $<\mathrm{LOD}$ & $<\mathrm{LOD}$ & $\begin{array}{c}125 \\
(<\mathrm{LOD}-208)\end{array}$ & $<\mathrm{LOD}$ & $\begin{array}{c}237 \\
(127-367)\end{array}$ \\
\hline $\mathrm{OP}_{1} \mathrm{EC}$ & $\begin{array}{c}61 \\
(60-63)\end{array}$ & $\begin{array}{c}62 \\
(60-65)\end{array}$ & $\begin{array}{c}62 \\
(60-64)\end{array}$ & $\begin{array}{c}61 \\
(60-62)\end{array}$ & $<\mathrm{LOD}$ & $\begin{array}{c}117 \\
(<\mathrm{LOD}-327)\end{array}$ & $<$ LOD & $\begin{array}{c}53 \\
(<\mathrm{LOD}-112)\end{array}$ & $<\mathrm{LOD}$ \\
\hline $\mathrm{OP}_{2} \mathrm{EC}$ & $\begin{array}{c}4374 \\
(3982-5003)\end{array}$ & $\begin{array}{c}16755 \\
(15642-17692)\end{array}$ & $\begin{array}{c}3659 \\
(2460-4541)\end{array}$ & $\begin{array}{c}13471 \\
(11869-15079)\end{array}$ & $<\mathrm{LOD}$ & $<\mathrm{LOD}$ & $<\mathrm{LOD}$ & $<$ LOD & $<\mathrm{LOD}$ \\
\hline $\mathrm{OP}_{1} \mathrm{EO}$ & $\begin{array}{c}49 \\
(48-51)\end{array}$ & $\begin{array}{c}50 \\
(49-52)\end{array}$ & $\begin{array}{c}499 \\
(375-672)\end{array}$ & $\begin{array}{c}93 \\
(52-163)\end{array}$ & $<\mathrm{LOD}$ & $\begin{array}{c}1062 \\
(<\mathrm{LOD}-4249)\end{array}$ & $<\mathrm{LOD}$ & $\begin{array}{c}277 \\
(<\mathrm{LOD}-561)\end{array}$ & $\begin{array}{c}320.5 \\
(222-446)\end{array}$ \\
\hline $\mathrm{OP}_{2} \mathrm{EO}$ & $\begin{array}{c}25 \\
(25-26)\end{array}$ & $\begin{array}{c}26 \\
(25-27)\end{array}$ & $\begin{array}{c}125 \\
(99-156)\end{array}$ & $\begin{array}{c}112 \\
(93-128)\end{array}$ & $<\mathrm{LOD}$ & $\begin{array}{c}457 \\
(136-1307)\end{array}$ & $<\mathrm{LOD}$ & $\begin{array}{c}81 \\
(<\mathrm{LOD}-112)\end{array}$ & $\begin{array}{c}122 \\
(64-184)\end{array}$ \\
\hline $\mathrm{OP}_{3-12} \mathrm{EO}$ & 196 & 194 & 83 & 37 & $129^{*}$ & $2017 *$ & $80^{*}$ & $375^{*}$ & $161^{*}$ \\
\hline
\end{tabular}

Note: $\quad$ LOD denotes below the MDL. To calculate the total concentration of the alkylphenolic compounds, half of the MDL was used for those that are <LOD. "When calculating the combination of alkylphenolic compounds, the concentration that is $\angle \mathrm{LOD}$ of a given analyte was set to half the MDL.

CAS - Carbonaceous activated sludge plant; N/DN - nitrifying/denitrifying activated sludge plant;N/DN-P nitrifying/denitrifying with phosphorus removal activated sludge plant; RAS - return activated sludge; SAS - surplus activated sludge. 